\title{
Research on the Application of Prefabricated Buildings in Infrastructure Projects of University in the Western Region
}

\author{
Dang Wenqiang ${ }^{1, a}$ \\ ${ }^{1}$ Infrastructure Department of Northwestern Polytechnical University, Xi'an, Shaanxi, China
}

\begin{abstract}
At present, prefabricated buildings are in a period of rapid development in my country, and ordinary colleges and universities are also in a stage of rapid development striving for world-class. Infrastructure construction is a strong guarantee for the development of universities, and the scale of construction is increasing every year. Taking advantage of the leading role of universities in the application of cutting-edge technology, researching the promotion of prefabricated buildings in basic construction projects in universities not only conforms to the development concept of green campuses, but also promotes the wide application of prefabricated buildings, which has a strong demonstration effect.
\end{abstract}

\section{Preface}

Chinese President Xi Jinping put forward the innovative, coordinated, green, open and shared development concept at the second plenary session of the Fifth Plenary Session of the 18th CPC Central Committee. The 19th National Congress of the Communist Party of China put forward the requirement of "promoting green development and launching actions such as the creation of conservation-oriented institutions, green families, green schools, green communities, and green travel". The core of the so-called green school lies in shaping a sustainable cultural atmosphere and environmental literacy. The "Assessment Standard for green building" (GB/T50378-2019) points out that green buildings save resources, protect the environment, reduce pollution, provide people with healthy, applicable and efficient use High-quality buildings that live in harmony with nature, and use structural systems and building components that meet the requirements of industrialized construction as a bonus item for improvement and innovation.

Industrialized construction is a prefabricated building. It is a construction technology that considers quality, schedule, and cost control based on the whole life cycle, and is one of the important means to achieve green buildings.

\section{Briefly introduce the prefabricated building and its development}

A prefabricated building is a building assembled on site by using prefabricated parts such as the main structure above the outdoor floor of a single building, retaining walls and internal partition walls, decoration and equipment pipelines. $^{[1]}$ Compared with traditional cast-in-place buildings, prefabricated buildings have the

${ }^{a}$ Corresponding author: dangwenqiang@nwpu.edu.cn characteristics of integration and refinement. ${ }^{[2]}$ Based on standardized production, they have obvious effects in construction project schedule control, quality management, and cost control in the whole life cycle.

Prefabricated buildings have entered a relatively mature stage in Western countries, but they are still in their infancy in my country. Since 2015, China has actively guided the development of prefabricated buildings at the policy level, and accelerated the formulation and promulgation of related technical standards and evaluation standards at the same time, which greatly promoted the development of prefabricated buildings.

The growth data of prefabricated building area comes from the statistics of the Ministry of Housing and Urban-Rural Development,as shown in Figure 1.

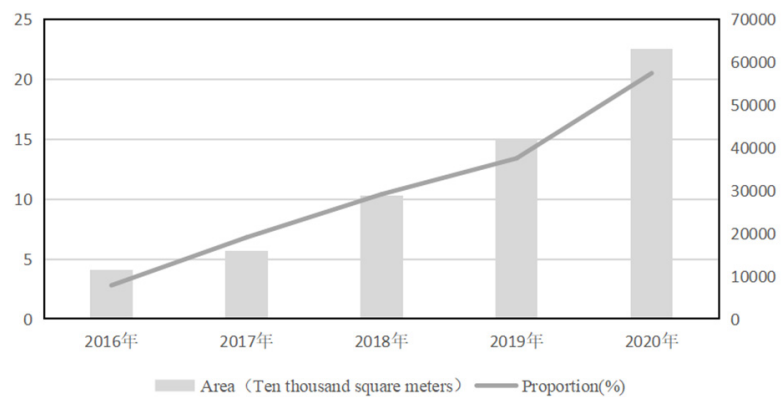

Figure 1. Construction area and proportion of prefabricated buildings nationwide from 2016 to 2020 .

At present, the development of prefabricated buildings in my country is still uneven, with rapid development in the southeast coastal areas and slower development in the western regions. Universities that are the frontiers of key technological innovation, especially those in the western region, should take the initiative to assume the responsibility and mission of promoting technological innovation. Universities should take the 
lead in exploring the application of prefabrication and related construction technologies in campus infrastructure projects, which can provide support for the promulgation and implementation of relevant national policies and promote the innovative development of the construction industry in the western region.

\section{Advantages of prefabricated buildings in universities}

\subsection{Common structural forms of buildings are suitable for assembly}

According to the "Building Area Indicators for Ordinary Colleges and Universities" (Building Standard 191-2018), the school buildings that must be configured in universities are divided into classrooms, experimental and training rooms and places, libraries, indoor sports rooms, and school administrative office rooms, departments and teachers' office rooms, teacher-student activity rooms, halls, student dormitories (apartments), canteens, single teachers' dormitories (apartments), logistics and ancillary rooms. Taking polytechnic universities with more than 20,000 students as an example, the proportion of dormitories (apartments), experimental sites, and classrooms in universities has reached nearly $70 \%$. Among these three types of buildings, multi-storey student dormitories mostly use frame or shear wall structures, and experimental sites and classrooms mostly use frame structures. The beams, walls (shear walls), columns, stairs and other components in this type of structure can all be easily prefabricated, and the corresponding technical standards and specification systems are relatively complete, and the market supply of components is relatively reliable.

Table 1. The building area index of universities.

\begin{tabular}{|c|c|c|}
\hline Category & $\begin{array}{c}\text { Per student } \\
\text { index }\end{array}$ & Percentage \\
\hline $\begin{array}{c}\text { Student dormitories } \\
\text { (apartments) }\end{array}$ & 10 & $37.59 \%$ \\
\hline $\begin{array}{c}\text { Experimental and training } \\
\text { rooms }\end{array}$ & 5.56 & $20.9 \%$ \\
\hline Classrooms & 2.95 & $11.09 \%$ \\
\hline $\begin{array}{c}\text { Logistics and ancillary rooms } \\
\text { Libraries }\end{array}$ & 1.57 & $5.9 \%$ \\
\hline $\begin{array}{c}\text { Departments and schoolteacher } \\
\text { rooms }\end{array}$ & 1.23 & $4.62 \%$ \\
\hline Canteens & 1.2 & $4.51 \%$ \\
\hline $\begin{array}{c}\text { Indoor sports rooms } \\
\text { rooms }\end{array}$ & 1.05 & $3.95 \%$ \\
\hline School administrative office & 0.6 & $2.26 \%$ \\
\hline
\end{tabular}

\begin{tabular}{|c|c|c|}
\hline $\begin{array}{c}\text { single teachers' dormitories } \\
\text { (apartments) }\end{array}$ & 0.4 & $1.5 \%$ \\
\hline Teacher-student activity rooms & 0.3 & $1.14 \%$ \\
\hline Halls & 0.24 & $0.9 \%$ \\
\hline
\end{tabular}

\subsection{Prefabricated buildings can meet the needs of flexible changes in space}

The architectural design of university infrastructure projects is demand-oriented and serves teaching and scientific research activities. The space requirements of such activities often change. The construction cycle of infrastructure projects is mostly from 36 to 60 months. During this period, the teaching methods, research team and student structure are prone to change, and more than once. As a result, it often appears that the day the building is completed and put into use is the day when the renovation begins. For traditional cast-in-place buildings, after the completion of the project, not only will it not bring benefits, but will also cause a lot of waste of resources.But for prefabricated buildings, this impact is much smaller,so it is suitable for buildings in universities.

\subsection{The prefabricated building can meet the requirements of the construction period}

Construction on a university campus will have an impact on the school's teaching, research and campus environment.Tower cranes, construction machinery, and heavy-duty transportation vehicles may even threaten the safety of teachers, students and employees. The shorter the construction period, the smaller the impact in this regard. In addition, the " 830 project" unique to universities interferes with normal progress control to a certain extent, often sacrificing quality due to rush work. Taking universities in Xi'an as an example, there are many factors that affect the progress of construction projects every year, such as: pollution control and haze reduction, prohibition of soil-related operations, autumn and winter rainy seasons are not conducive to earthwork.Especially due to the influence of noise at night, continuous pouring of large volumes of concrete is very difficult.However, prefabricated buildings can circumvent the above disadvantages.

First of all,the components used for on-site assembly in prefabricated buildings are produced in the factory, which is less affected by the climate and the environment and the progress is fast.Secondly,semi-finished or fully-finished components eliminate the need for plastering, embedded pipes and other processes, and can directly carry out the finishing layer construction, thus speeding up the project progress. Thirdly,the integrated design and production of buried pipelines and enclosure structures, as well as unified on-site installation, can greatly reduce errors, leakage and collisions between pipelines and structures, reduce rework and speed up progress.Finally,as the main assembly is dry construction 
method, it involves less work and is less affected by environmental protection policies.

\subsection{Prefabricated buildings can eradicate common quality problems in infrastructure projects in universities}

According to statistics on the quality problems that occurred within one year of the completion of a construction project in a university in the past five years, it is mainly concentrated in floor leakage, window seepage, poor wall flatness, poor weather resistance of paint facades, etc. The current construction methods are difficult to achieve a high level of quality. These common quality problems have plagued the ambition of universities to build a century-old university.The parts and components of the prefabricated building are factory-produced, and can even be 3D printed, with controllable quality and high precision; the on-site installation process can eliminate plastering and reduce construction and maintenance costs.

The fine quality of the prefabricated components can reduce or even eliminate the leveling layer, and the hollowing and cracking problems of the secondary plaster can be cured.The integrated design and production of the door and window frames and the enclosure structure can completely solve the problem of water seepage at the door and window opening. The integrated design and production of the insulation layer and the enclosure structure eliminates the need for the connection between the insulation layer and the enclosure structure, so that the insulation cracking and falling off can be cured.The integrated design and production of the finishing layer and the maintenance structure greatly reduces the maintenance cost in the later period.

\section{Resistance to the application of prefabricated buildings in universities}

\subsection{Lack of active application awareness}

In government approval, construction projects invested by universities are recognized as government investment projects, and are subject to upper limit requirements in terms of energy conservation and green building design. Taking Xi'an as an example, government-invested projects must adopt prefabricated buildings, and the prefabrication ratio must not be less than $30 \%$. However, in the planning stage, the traditional cast-in-place structure is still habitually designed. In the approval stage, in order to meet the requirements of the prefabrication ratio, the cast-in-place structure was simply replaced with prefabricated components. The system does not follow the rules and characteristics of assembly for systematic thinking and integrated design. The advantages of prefabricated buildings are revealed, but their shortcomings are fully demonstrated. For example, it is an laboratory building project of a university in Xi'an.This project has 3 floors above ground and 1 floor underground, with a total construction area of 36,000 square meters. The main structure adopts a reinforced concrete frame structure, and the foundation adopts an independent column base and a strip foundation under a reinforced concrete column. Since the prefabricated design was not considered in the design stage, and the approval was not passed in the construction permit stage, a simple replacement was carried out on the basis of the original structure design, so that the prefabrication ratio reached $30.2 \%$, but the cost increased by 4.06 million, and the prefabricated secondary design also lasted for more than 3 months.

\subsection{Lack of the cost concept in the whole life cycle}

Based on the prefabricated construction method of building industrialization, the original work of a large number of manual pouring is converted to factory standardized production, and only installation is carried out on site, which greatly reduces the dependence on labor workers and reduces labor costs. In recent years, the price of concrete has continued to rise, labor costs have been adjusted year by year, and the labor cost rise caused by the shortage of labor workers has continuously highlighted the low labor cost advantage of the prefabricated construction method.

At present, as the prefabricated buildings in our country are still in their infancy, the design standardization of prefabricated components and the low level of production and transportation scale have led to the increase in costs brought about by the prefabricated buildings more than the reduction, and the overall cost is increasing. With the continuous introduction of standards and specifications, the continuous improvement of the production supply chain, and the continuous maturity of the market transportation chain, this disadvantage of prefabricated buildings will gradually disappear. It is only a matter of time before the cost is flat with the traditional cast-in-place mode or even optimized. In addition, prefabricated buildings are easier to dismantle and reuse than traditional buildings, and can still show their value in the last stage of the life cycle.

\subsection{The application level of BIM and EPC is Relatively shallow}

The "Shaanxi Prefabricated Building Evaluation Standard" points out that BIM technology should be used in prefabricated buildings. The use of BIM technology for the design, production and construction management of prefabricated buildings can not only ensure standardized design, but also greatly benefit the accuracy of production and installation..$^{[3]}$

The "Guiding Opinions of the General Office of the State Council on Vigorously Developing Prefabricated Buildings"requires prefabricated buildings to adopt engineering procurement construction(EPC) in principle. According to the empirical values given in the "Management and Policy Guidelines for the Development of Prefabricated Buildings", the use of the 
EPC model can better utilize the advantages of prefabricated buildings and reduce the total cost of the project by $3 \%$ to $5 \% .{ }^{[4]}$ The EPC mode allows the construction party to participate in the design phase, thereby greatly reducing the problem of the connection between design and construction. But up to now, BIM technology and EPC mode are rarely used in university infrastructure. Still taking this university as an example, only one project used BIM technology to implement construction drawing collision detection, and no project adopted the EPC contracting model. As the "two wings" of prefabricated construction technology, the application depth of BIM technology and EPC contracting mode is insufficient, which also affects the effectiveness of prefabricated construction.

\section{Suggestions on the application of prefabricated buildings in university}

\subsection{Establishment stage}

Root the prefabricated building design concept in the establishment of infrastructure projects, and conduct a sufficient feasibility study on how to use prefabricated construction technology in the project, including the design level of local prefabricated buildings, the special review of construction drawings, the production capacity and transportation of prefabricated component manufacturers situation and so on. In the investment estimate, set aside the cost increase that may be brought about by the prefabricated building at this stage.At the same time, consider choosing the EPC contracting method, which has laid a good foundation for the application of prefabricated buildings.

\subsection{Design stage}

The design work has a significant impact on the project, according to W.E.Back's statistics of 20 U.S. projects in 1998 ,as shown in Table 2.

Table 2. The impact of design work on the project.

\begin{tabular}{|c|c|}
\hline Influencing factors & $\begin{array}{c}\text { Proportion of the entire } \\
\text { project }\end{array}$ \\
\hline Labor cost & $28 \%$ \\
\hline Construction period & $22 \%$ \\
\hline Determine the investment & $80 \%$ \\
\hline $\begin{array}{c}\text { Determine production } \\
\text { efficiency }\end{array}$ & $70 \% \sim 80 \%$ \\
\hline Sources of quality problems & $40 \%$ \\
\hline
\end{tabular}

Implantable assembly gene in the design stage of infrastructure project, and carry out design work around the laws and characteristics of prefabricated buildings.
Conduct research on the market production of prefabricated components, prioritize the use of prefabricated components with large production capacity and sufficient supply, and entrust a qualified construction drawing review agency to conduct special prefabricated technical reviews of design drawings. ${ }^{[5]}$ In addition to building structure majors, installation majors should also actively participate in prefabricated design to integrate pipeline installation and structure.

\subsection{Bidding stage}

In the design bidding documents, it is necessary to clarify that the design unit should clarify the component types, specifications and connection methods of the prefabricated building, draw detailed diagrams of the nodes; require the use of BIM models for bidding. In the bidding documents for general construction contracting, it is necessary to specify that the construction unit shall combine the prefabricated construction process to prepare a scientific and reasonable construction organization design and quality and safety special plan, and the cost of measures to ensure quality and safety shall be fully considered in the quotation. In the bidding documents for supervision, it is necessary to clarify the responsibility for the preparation of prefabricated construction supervision planning and implementation rules, and the supervision of component production quality and entry verification.

\subsection{Construction stage}

Work with the construction unit to propose construction quality and safety guarantee measures for structural construction and main structural component connections. Establish a system for the first trial assembly of components and prototypes, and strengthen the management of key processes such as on-site reinforcement sleeve connection and grouting. Sort out the management concept of construction marks, retain quality assurance data and image data, and especially ensure that the image data of concealed projects is complete and complete. Strengthen the quality control of component production, establish a system confirmed by the design unit before component production, and entrust a qualified building component inspection agency to inspect the factory components.

\subsection{Acceptance stage}

Relying on departments of local quality supervision, energy-saving supervision and inspection agencies, test the installation and of core components of the prefabricated building to ensure that the design requirements are met. At the same time, the acceptance should be done well with the school's operation management department to ensure the normal operation and maintenance of the prefabricated building. 


\section{Conclusion}

To promote prefabricated buildings in university infrastructure projects, universities must first conform to the trend of building industrialization and lead the refinement, integration, and conservation of construction projects. Secondly, it is necessary to carry out prefabricated building design based on the whole life cycle, follow its characteristics and rules, maximize the strengths and avoid weaknesses, and maximize the benefits. In addition, continue to explore the application of BIM-based digital construction technology and highly integrated engineering general contracting mode in university infrastructure projects to help the widespread application of prefabricated buildings.

\section{References}

1. Department of Housing and Urban-rural Development of Shaanxi Province(2020)Shaanxi Province Standard for Assessment of Prefabricated Building.Shaanxi Province Construction Standard Design Station, The Xi'an.

2. Hu,WB. (2020)Guide for Full Cost Management of Prefabricated Buildings-planning, design, recruitment.China Architecture \& Building Press, The Beijing.

3. Liu,DW.(2021)Application of BIM Technology in the Whole Life Cycle of Prefabricated Buildings.Southeast University Press. The Nanjing.

4. Liu,DW.(2021)General Contracting Management of Prefabricated Construction.Southeast University Press. The Nanjing.

5. Wang BH. (2020) Prefabricated Concrete Building-analysis of Design Problems and Countermeasures. China Machine Press, The Beijing. 